\title{
In Memory of Lee Goodglick: A Friend and A Scholar
}

\author{
Benjamin Bonavida \\ David Geffen School of Medicine Jonsson Comprehensive Cancer Center University of California at Los Angeles; \\ 10833 Le Conte Ave. Los Angeles, CA 90095; bbonavida@mednet.ucla.edu
}

With deep sorrow and sadness that Lee's amazing life was cut short. I have had the privilege to get to know Lee for many years and we rapidly established a strong bonding of friendship and research collaborations. He was always available to be of help or for advice with open heart and compassion. Lee was a real human full of life, joy and happiness and a uniquely trustworthy individual.

Lee and I got together very frequently at UCLA and we usually met at the courtyard or in his office. I liked to visit him in his office and help myself to a variety of chocolates that he had stored in one of his desk drawers. He never hesitated to offer these and other sweets, although, ironically, I never witnessed him eating any.

Scientifically, Lee has helped me and many of my students and fellows in the art of performing and analyzing data generated from the specific expression of gene products in a variety of cancers. He was critical in his analysis and many research meetings were held to go over the data prior to their preparation for publication. Fortunately, we worked together closely and exchanged ideas for many years and my laboratory benefited from these interactions. Several coauthored research publications with Lee emanated from these collaborations and are listed below. ${ }^{1-4}$

Lee had a great sense of humor and he always preferred a "tea time" rather than "coffee time." He and I confided in many issues and he has instilled in me a good sense of self-security and reasoning. He was full of entrepreneurial ideas, some of which we entertained and discussed thoroughly. He had managed to successfully earn an MBA at UCLA along with his full-time academic responsibilities. He was determined to venture into a new enterprise based on his expertise and his intuition. There was no doubt in my mind that he would have succeeded and contributed to help humanity.

Lee was very fond of his parents and his siblings. He loved them as well as being loved, and loved his nephews and nieces. He was a role model for them. He was at a young age a family man, and when time came he had his own family and got married to his love, Rietta. I recall vividly his greatest joy when he first met Rietta and he knew immediately that she was the one and the love of his life. He was committed to her and I was honored to attend their wedding ceremony. Thereafter, an additional love in his life was the arrival of his son, Joseph.

Unfortunately, Lee's death was sudden and unexpected. He had a fulfilled life, though very short. His life was taken away very soon and it is hard to imagine why tragic things like this happen to such good people. I continue to have visions of Lee's figure every time I pass through the UCLA's corridor where his office and laboratory were housed. I miss him very much. Lee has left a legacy to all of us that we shall follow and honor. He will forever be missed.

\section{REFERENCES}

1. Seligson D, Horvath S, Huerta-Yepez S, Hanna S, Garban H, Roberts A, Shi T, Liu X, Chia D, Goodglick L, and Bonavida, B. Expression of transcription factor Yin Yang 1 in prostate cancer. International Journal of Oncology. 2005;27:131-41.

2. Seligson D, Hongo F, Huerta-Yepez S, Mizutani Y, Miki T, Yu Y, Horvath S, Chia D, Goodglick L, Bonavida B. Expression of X-linked inhibitor of apoptosis protein is a strong predictor of human prostate cancer recurrence. Clin Cancer Res. 2007;13:6056-63.

3. Yoon NK, Seligson DB, Chia D, Elshimali Y, Sulur G, Li A, Horvath S, Maresh E, Mah V, Bose S, Bonavida B, Goodlick L. Higher expression levels of 14-3-3sigma in ductal carcinoma in situ of the breast predict poorer outcome. Cancer Biomark. 2009;5:215-24. 
4. Huerta-Yepez S, Yoon NK, Hernandez-Cueto A, Mah V, Rivera-Pazos CM, Chatterjee D, Vega MI, Maresh EL, Horvath S, Chia D, Bonavida B, Goodglick L. Ex- pression of Phosphorylated Raf kinase inhibitor protein (pRKIP) is a predictor of lung cancer survival. BMC Cancer. 2011;11:259-68. 